\title{
The Documents Expediting Project, 1946-2004
}

\author{
Gwen Sinclair
}

$\mathrm{T}$ he Documents Expediting Project (DocEx), an acquisition and distribution service for federal documents that operated out of the Library of Congress (LC) from 1946 to 2004, was an important source of non-depository items, second copies, and fugitive documents. In addition to distributing documents to subscribing libraries and other organizations, DocEx supplied documents to the Superintendent of Documents for inclusion in the Monthly Catalog of United States Government Publications (MoCat). DocEx stands as a model of cooperation between libraries, library associations, LC, federal agencies, the Superintendent of Documents, and vendors to facilitate the acquisition and distribution of millions of documents that would otherwise have disappeared.

\section{Origins and Early History, 1946-53}

During World War II, dozens of federal agencies were created to support the war effort, including the Office of Price Administration, Office of War Information, War Production Board, War Food Administration, War Shipping Administration, Strategic Bombing Survey, and many others. These agencies produced masses of documents, many of which were not printed or distributed by the Government Printing Office (GPO). This explosion in government publications was reflected in the title of the American Library Association (ALA) Public Documents Committee's 1942 meeting: "World War II versus Public Documents." At the close of the war, these wartime agencies and the armed services needed to dispose of vast quantities of surplus publications in an expeditious manner. More than a few of the documents had to be declassified before they could be distributed, so the agencies hurried to review them in preparation for disposal.

At the same time, LC and other libraries were frustrated in their efforts to obtain what were called "processed publications." These were "fugitive" publications that were duplicated by federal agencies through processes like mimeography and were therefore not printed or distributed by the Superintendent of Documents. Libraries that attempted to directly contact agencies often found that they did not have the staffing or infrastructure to maintain mailing lists or distribute publications. Even "full” depositories did not receive anywhere near all of the federal documents published, and in fact the number of documents not distributed by GPO equaled the quantity that was available through the Superintendent of Documents. ${ }^{2}$

In October 1945, Librarian of Congress Luther Evans decided that the best approach would be to send letters to federal agency heads asking for their cooperation in the retention of surplus documents, which would allow their distribution to libraries through the Superintendent of Documents. The War and Navy Departments immediately complied, issuing orders that offices, branches, and installations should send up to 150 copies of documents that had not previously been provided to LC. The responses of other agencies were similarly encouraging. The Office of War Information agreed to transfer phonograph records, motion pictures, and books that had been accumulated for distribution overseas. The Publication Board of the Department of Commerce (predecessor of National Technical Information Service), which distributed technical publications such as translations, also issued a circular letter agreeing to participate. ${ }^{3}$

Earlier in 1945, ALA, the Association of Research Libraries (ARL), Special Libraries Association (SLA), and American Association of Law Libraries (AALL) had combined forces to develop a strategy for improving the distribution of wartime materials and fugitive publications. The result was the formation of a Joint Committee on Government Documents ("Joint Committee"). The idea for a "documents expediter" originated with ARL, which had studied the possibility of stationing an individual in Washington, DC, to work with agencies to procure documents. ${ }^{4}$ 
The Joint Committee, in cooperation with LC, decided to establish DocEx, a program to distribute all of the publications that were not available through the Superintendent of Documents. The chair of the committee, Homer Halvorson of Johns Hopkins University, sent a letter to 178 libraries, which included ARL members, National Association of State Libraries members, selected large public libraries, and selected college and university libraries that were not ARL members. The letter was meant to gauge their interest in participating in DocEx, and thirty-two indicated that they were willing to give financial support to the effort. LC provided space in its Exchange and Gift Division, and Halvorson hired Walter B. "Bart" Greenwood, formerly of the Ethnogeographic Board, as the first Documents Expediter in 1946. The Documents Expediter was tasked with establishing relationships between government agencies and libraries that were interested in receiving their publications. In addition to supplying LC and subscribing libraries, the project also provided copies of documents to the Superintendent of Documents for listing in MoCat. ${ }^{5}$

In its early years, DocEx provided a mechanism for wartime agencies to distribute surplus documents that otherwise would not have been disseminated because most agencies did not have the staff or expertise to set up their own distribution systems. DocEx was able to distribute recently declassified documents quickly. The Documents Expediter even persuaded some agencies to initiate declassification for certain categories of publications. DocEx also developed liaison relationships with declassification committees of government agencies to learn of declassified documents as they were released. ${ }^{6}$

In DocEx's first year, Greenwood negotiated with agencies to send specific publications to DocEx participants. These included the US Maritime Commission, Federal Communications Commission, Inter-American Defense Board, Advisory Committee on Voluntary Foreign Aid, Pan American Union, Bureau of Mines, and Securities and Exchange Commission. An agency-by-agency list of the number of titles distributed included Army technical manuals, field manuals, Civil Affairs handbooks, and technical bulletins; Navy Bureau of Ships and Bureau of Aeronautics publications; Army and Navy unit histories; and miscellaneous other titles. ${ }^{7}$ DocEx distributed documents such as Office of Strategic Services maps, Petroleum Administration reports on German oil technology, and Office of War Information audiovisual materials. ${ }^{8}$ It also distributed documents obtained by LC's Mission in Europe, such as the Office of the Military Government of the U.S.'s Military Government Regulations, and it assembled copies of Official Gazette of the U.S. Army Military Government in Korea. ' In August 1946, DocEx began sending a newsletter, Documents Expediting

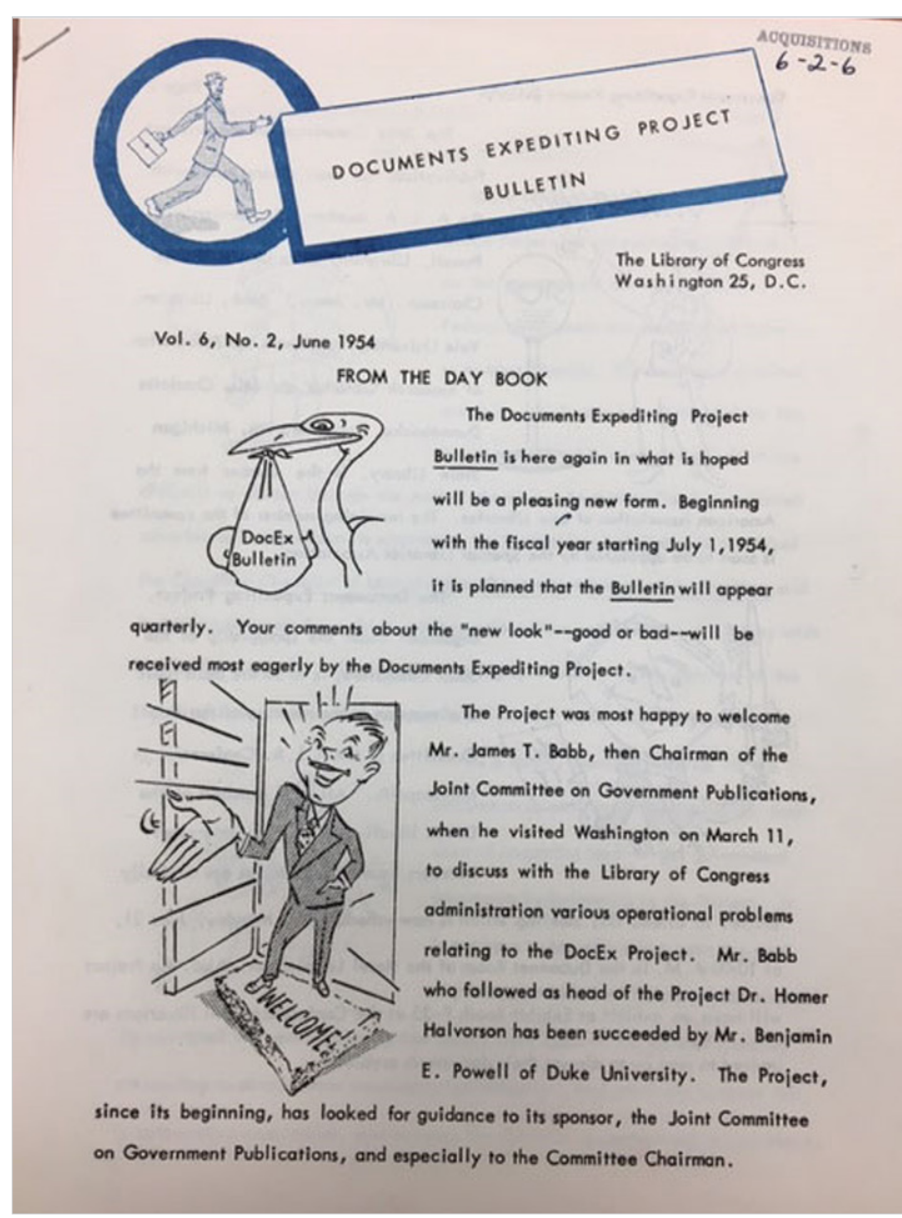

Figure 1. Cover of Documents Expediting Project Bulletin, vol. 6, no. 2 (June 1954).

Project Bulletin, to participating libraries to highlight new or forthcoming publications (see figure 1).

In 1947, DocEx distributed additional wartime publications, including the Far Eastern Commission's Press Release Series; the Office of Foreign Agricultural Relations' International Agricultural Collaboration Series, including reports of the Agricultural Mission to China; and the War Department Civil Affairs Division's Weekly Report on Japan to the Far Eastern Commission and SCAP Directives to the Imperial Japanese Government. DocEx also prepared sets of United Nations Relief and Rehabilitation Administration documents for interested libraries. The Department of Commerce's Office of Technical Services (OTS), which distributed captured German and Japanese scientific and technical documents, was a source for 400,000 German documents acquired by DocEx. DocEx distributed thousands of British Intelligence Objectives Subcommittee (BIOS), Combined Intelligence Objectives Subcommittee (CIOS), and Field Information Agency, Technical (FIAT) reports. The Bulletin also reported that DocEx was attempting to obtain a sixty-volume series reviewing the progress of German science during the war years from OTS. ${ }^{10}$ 
In 1948, DocEx continued to acquire both wartime publications and fugitive publications from agencies, including the Office of Strategic Services Research and Analysis Branch, State Department European Recovery Program, Office of Scientific Research and Development, Economic Cooperation Administration, Munitions Board, and defense agencies. ${ }^{11}$ Before the Atomic Energy Commission established its own depository system, DocEx distributed its declassified reports. ${ }^{12}$

Many large research libraries, large public libraries, and state libraries joined DocEx in the first fifteen years of the project. Each member library was assigned a priority number based on the dollar amount of its subscription and its date of entry into DocEx. When there were insufficient copies of a document for all DocEx members, the priority list determined which libraries would be recipients. Similar to GPO's lighted bin system, which was once used to prepare materials for shipment to depository libraries, publications were distributed into boxes according to this numerical priority. When enough material had accumulated for a shipment, the boxes were packed and shipped. $^{13}$

DocEx distributed wartime publications to both subscribing libraries and to federal depositories that selected 100 percent of available documents. By 1950, DocEx had completed the distribution of wartime documents. It increased its efforts to have agencies send documents directly to libraries. At this point, the project began taking orders for publications listed in MoCat that were not distributed through the Federal Depository Library Program (FDLP). ${ }^{14}$ In the early 1950s, DocEx distributed a variety of State Department publications, including Office of Intelligence Research declassified OIR Reports and back copies of US-sponsored German-language periodicals Heute, Der Monat, Die Amerikanische Rundschau, and Neue Auslese. DocEx continued to provide documents from occupied countries and territories, including the proceedings of the Japanese and German war crimes trials. ${ }^{15}$

Greenwood saw to it that libraries were added to agencies' existing mailing lists and he encouraged other agencies to develop lists. The Naval Research Laboratory, Atomic Energy Commission, Civil Aeronautics Administration, Tariff Commission, Weather Bureau, and Federal Public Housing Administration were among those agencies with which DocEx arranged mailing lists. DocEx concentrated on identifying publications that were mentioned in news articles for inclusion in the program. The project also sought publications from international agencies with offices in Washington, including the Far Eastern Commission, Inter-American Defense Board, and the War Department's Civil Affairs Division. ${ }^{16}$
In 1949, John L. Andriot succeeded Greenwood as Documents Expediter. He is primarily remembered for his monumental Guide to U.S. Government Publications. To attract new members to DocEx, Andriot attended library conferences armed with a one-page information sheet that explained DocEx's services. Prospective members learned first that DocEx acquired and distributed fugitive publications. Second, it arranged for libraries to be added to agencies' mailing lists. Third, it acquired requested publications on behalf of subscribers by allowing libraries to send a consolidated list of documents desired to DocEx, thereby saving them from having to correspond with each agency separately. The handout also explained that DocEx documents were not available through any other means because some agencies did not maintain mailing lists or have distribution systems. Andriot reported that many librarians were unaware of DocEx's valuable services. ${ }^{17}$

Andriot was particularly interested in compiling a comprehensive list of non-depository documents. His first attempt, Classified Checklist of United States Government Processed Publications (1951), was designed to simplify the ordering of fugitive and difficult-to-obtain publications. Prior to the compilation of the Classified Checklist, libraries had no alternative but to review each issue of MoCat for items that were not distributed through the depository system before requesting them from DocEx. ${ }^{18}$

Beginning in 1951, DocEx attempted, with limited success, to acquire congressional committee prints but was unable to obtain enough copies for distribution. Instead, the project provided a copy of each print to University Microfilms, Inc. (UMI) for microfilming. DocEx similarly contributed to Readex Microprint Corporation's microprint edition of nondepository documents, supplying copies of documents to the Superintendent of Documents for this purpose. ${ }^{19}$

In 1952, DocEx considered distributing documents on microfilm. The January 1952 issue of the Bulletin included a sample of microfilmed Foreign Broadcast Information Service (FBIS) Daily Reports, which was meant to demonstrate the quality of the Diebold Flow-Film camera. DocEx proposed three types of publications to distribute on microfilm: the FBIS Daily Reports and Foreign Radio Broadcasts, committee prints, and Voice of America (VOA) scripts. ${ }^{20}$ In a December 1951 meeting, LC Exchange and Gift Division chief Alton Keller, Halvorson, and Andriot decided not to pursue microfilming. ${ }^{21}$ Apparently, a decision was later made to have the VOA scripts and FBIS Daily Reports microfilmed by the LC Photoduplication Service, which provided them to DocEx for distribution. ${ }^{22}$ 


\section{Peak Years, 1954-79}

In an article for Library Journal, Andriot highlighted the availability of congressional committee prints through DocEx, noting that many of the prints were not listed in MoCat. He also explained the lengths to which the Documents Expediter would go to obtain publications, such as making phone calls and personal visits to agencies. ${ }^{23}$ Further evidence of the legwork involved in acquiring publications appeared in the June 1954 Bulletin:

From July 1, 1953 to March 31, 1954 the Documents Expediter and his assistant made 2,083 visits to federal agencies and congressional committees. They acquired 149 committee prints and 187 other titles. In addition to making personal visits, they read the Congressional Record, [Public Affairs Information Service], Public Management Sources, Recent Publications on Governmental Problems, proof sheets of LC catalog cards, and proofs of $\mathrm{MoCat}$ to find additional material. ${ }^{24}$

From 1946 to 1954, DocEx operated under an agreement between the Joint Committee and the Librarian of Congress. In 1954, arrangements were formalized through a contract signed by Ben Powell, chairman of the Joint Committee, and Luther Evans. ${ }^{25}$ That same year, Andriot left LC to devote his time to the Documents Index Company he had established with his wife Jeanne. ${ }^{26}$ His successor was Allen L. Heyneman, an acquisitions specialist at LC. He resigned in 1955 and was replaced by Shirley Bystrom of the Exchange and Gift Division. ${ }^{27}$ She continued to attend library conferences and visit libraries to recruit more members.

Ironically, the Readex microprint created serious competition for DocEx. LC's 1955 Annual Report noted:

The advent of the Readex Microprint edition of nondepository Federal documents has affected the operations of the Documents Expediting Project and has led to a search for additional revenue. Efforts to increase the number of participating libraries met with some success, the minimum subscription rate was raised, and libraries were asked to pay postal charges on materials received. ${ }^{28}$

During the early 1960s, DocEx was successful in attracting many new members by advertising both the materials it routinely distributed and the services it provided to libraries in procuring hard-to-find titles. In 1968, the contract with the Joint Committee ended, and DocEx was attached to the Federal Documents Section within the Exchange and Gift Division. ${ }^{29}$ By 1970, DocEx had 142 participating libraries and five staff members: the Documents Expediter, Assistant Documents Expediter, Documents Expediting Assistant, Shipping Assistant, and Clerk-Typist. The peak membership was 144 , reached in $1975 .{ }^{30}$

Not all libraries found DocEx membership to be of value. ARL libraries were already losing interest in DocEx as early as 1959. During the annual meeting that year, it was suggested that DocEx "had probably outlived its usefulness" and ARL voted to recommend to the Joint Committee that its participation in DocEx be phased out. ${ }^{31}$ Harban S. Chona of Oregon State University (OSU) may have expressed the views of some libraries when he wrote of his disappointment with DocEx. Responding to a positive article by former Assistant Documents Expediter John Brewster, Chona described how his library had joined and subsequently quit DocEx twice. OSU found that DocEx provided documents that mostly duplicated what the library received via direct mail or through the FDLP, while it did not provide needed documents. He argued that it was more efficient for his library to obtain documents by requesting them from agencies. ${ }^{32}$

During the 1970s, DocEx distributed more congressional material, including duplicates of congressional hearings that it acquired from LC, congressional committees, and other agency libraries. ${ }^{33}$ It distributed 537 committee prints to members in FY1973 and it provided copies of committee prints to the GPO Library for permanent retention and inclusion in MoCat. ${ }^{34}$ However, some libraries withdrew from DocEx when the committee prints became available through the FDLP in $1976 .{ }^{35}$ Central Intelligence Agency (CIA) publications were a popular addition to DocEx's offerings. The CIA began to provide documents, primarily Reference Aids and maps, to DocEx in 1972. In 1979, the FDLP began to distribute these CIA publications. DocEx also distributed Reference Aids to non-members for a flat rate. ${ }^{36}$ Much of what DocEx provided to members were unneeded duplicates that had been sent to LC by federal agencies. The greatest value of DocEx continued to be its pursuit of documents requested by individual libraries. It achieved greater success in requesting documents from agencies than individual libraries could because of its standing as a legislative branch agency. ${ }^{37}$ DocEx proudly reported that it was able to fill 62 percent of special requests. ${ }^{38}$ 


\section{DocEx's Later Years, 1980-2004}

Coverage of DocEx in the library literature was practically nonexistent after the mid-1970s, nor did the project merit mention in the Annual Report of the Librarian of Congress or the Library of Congress Information Bulletin beyond the reporting of statistics. Evidently, DocEx did not market its services much in its later years, and the staff focused their efforts on providing excellent service to existing members. In 1980, DocEx notified members that it would expand the number of agencies whose documents it distributed and that it would produce a monthly newsletter. ${ }^{39}$ There is no evidence, however, that the newsletter was ever issued.

In 1981, DocEx became a separate section in the Acquisitions and Overseas Operations Division. ${ }^{40}$ Donnie Draughon, Jr. was the last to hold the title "Documents Expediter." Following his retirement in 1983, David Bloxsom, who held the title "Head, Documents Expediting Project/Section," led the project until he retired at the end of 1996. Thereafter, DocEx was nominally headed by the Assistant Chief, Exchange and Gift Division. A reorganization at LC in 1998 placed DocEx in the Government Documents Section of the Anglo-American Acquisitions Division. The reorganization made DocEx employees permanent, whereas they had previously been in “indefinite" appointments. ${ }^{41}$

As an increasing number of documents distributed by DocEx became available through the FDLP in the 1980s and 1990 s, there was further attrition in the membership. Nevertheless, many librarians still found DocEx useful for obtaining duplicate copies, print of materials only distributed by the FDLP in microfiche, and documents not received on claim. DocEx also supplied libraries with second copies of popular reports, which it acquired by requesting an additional twenty copies from GPO's print run. ${ }^{42}$ By 2003, the membership had dropped to eighty-seven libraries, and DocEx had only two employees assigned to the project part-time. ${ }^{43} \mathrm{LC}$ 's decision to end DocEx was prompted by the decline in membership, which was in part due to the discontinuation of CIA publications and the increasing availability of documents online. Michael W. Albin, Chief of the Anglo-American Acquisitions Division of LC, notified participating libraries of the project's discontinuation as of September 30, 2004, stating that the service was no longer self-supporting due to the participation of fewer libraries. ${ }^{44}$ While some librarians lamented its demise, most recognized that the availability of documents on agency websites meant that DocEx's time had come and gone. In acknowledgement of its accomplishments, the Depository Library Council to the Public Printer (DLC) commended DocEx, citing its contributions and outstanding service at the 2004 DLC Spring meeting. ${ }^{45}$

\section{Conclusion}

About 220 libraries participated in DocEx throughout its lifespan, and many still hold extensive collections of publications acquired through DocEx. It was an unparalleled source of documents to fill gaps, and it enabled the acquisition of fugitive publications not distributed through the FDLP. Thanks to DocEx, participating libraries were able to assemble comprehensive federal documents collections that extended well beyond FDLP materials. Today, as a result of digitization projects in former DocEx member libraries, many publications distributed by DocEx are freely available in online repositories such as HathiTrust. DocEx's legacy is a testament to the dedication and efforts of its staff and the participating libraries.

The author gratefully acknowledges Joseph Mahar, Head of the Surplus Book Program at the Library of Congress and former DocEx librarian, for sharing his knowledge of DocEx.

Gwen Sinclair (gsinclai@hawaii.edu), Chair, Government Documents \& Maps Department, University of Hawai'i at Mānoa Library.

\section{References}

1. Susan Lee Grabler, "ALA Public Documents Committee, 1876-1956," Journal of Government Information 22, no. 1 (1995).

2. Homer Halvorson, "The Documents Expediting Project in Its First Year," College and Research Libraries 9 (1948): 16.

3. Library of Congress, Annual Report of the Librarian of Congress for the Fiscal Year Ending June 30, 1946 (Washington, DC: Library of Congress, 1947), 267-68.

4. Annual Report of the Librarian of Congress for the Fiscal Year Ending June 30, 1946, 267-68.

5. Halvorson, 17.

6. Library of Congress, Exchange and Gift Division Manual (Department \& Divisional Manuals no. 6) (Washington, DC: Library of Congress, 1950), 24-25.

7. Documents Expediting Project Bulletin 1, no. 3 (October 1946).

8. John Y. Cole and Jane Aikin, eds., Encyclopedia of the Library of Congress (Washington, DC: Library of Congress, 2004), 474.

9. Halvorson, 17. 
10. Documents Expediting Project Bulletin 1, no. 5 (June 1947).

11. Library of Congress, Annual Report of the Librarian of Congress for the Fiscal Year Ending June 30, 1948 (Washington, DC: Library of Congress, 1949), 85.

12. John L. Andriot, "Government Serials at Mid-Century," Serials Slants Quarterly 2, no. 4 (April 1952): 1-10.

13. Halvorson, 17.

14. Library of Congress, Annual Report of the Librarian of Congress for the Fiscal Year Ending June 30, 1950 (Washington, DC: Library of Congress, 1951), 110.

15. Documents Expediting Project Bulletin 4, no. 3 (June 1951): 1.

16. Halvorson, 17.

17. John L. Andriot to Luther Evans, October 14, 1949, Box 404, folder Acq. 6-2-6, LC Central Files, Library of Congress, Washington, DC.

18. Documents Expediting Project Bulletin 4, no. 3 (June 1951): 1.

19. Library of Congress, Annual Report of the Librarian of Congress for the Fiscal Year Ending June 30, 1953 (Washington, DC: Library of Congress, 1954), 25.

20. Documents Expediting Project Bulletin 5, no. 1 (January 1952): 1.

21. Alton Keller to Luther Evans, December 19, 1951, Box 404, folder Acq. 6-2-6., LC Central Files, Library of Congress, Washington, D.C.

22. Association of Research Libraries, Annual Report on the Documents Expediting Project, 1952-1953, Appendix IV to Minutes of the Forty-First Meeting of the Association of Research Libraries, June 21, 1953, 35, https://bit.ly /2SrjPAt.

23. John L. Andriot, "Documents Expediting Project," Library Journal 77 (April 15, 1952): 693-95.

24. Documents Expediting Project Bulletin 6, no. 2 (June 1954): 2-3.

25. John W. Brewster, "Doc Ex," Wilson Library Bulletin 44 (May 1970): 943.

26. William L. Olbrich, Jr., "Androit's [sic] Guide: A Flawed Classic?" Government Publications Review 13 (1986): 473-89; Alton H. Keller to Verner W. Clapp, April 19, 1954, Box 404, folder Acq. 6-2-6., LC Central Files, Library of Congress, Washington, DC. In fact, Andriot had sold the company to friends while he worked as the Documents Expediter to avoid a conflict of interest, but he wanted to continue working on the Classified Checklist and other projects, and it was not possible for him to do that while employed at DocEx.
27. Documents Expediting Project Bulletin 8, no. 1 (December 1955): 1.

28. Library of Congress, Annual Report of the Librarian of Congress for the Fiscal Year Ending June 30, 1955 (Washington, DC: Library of Congress, 1956), 13-14.

29. Library of Congress, Annual Report of the Librarian of Congress for the Fiscal Year Ending June 30, 1981 (Washington, DC: Library of Congress, 1982), 58.

30. Library of Congress, Annual Report of the Librarian of Congress for the Fiscal Year Ending June 30, 1975 (Washington, DC: Library of Congress, 1976), 18.

31. Association of Research Libraries, Minutes of the FiftySecond Meeting of the Association of Research Libraries, January 26, 1959, https://bit.ly/2CHiv6X.

32. Harban S. Chona, "Doc Ex Revisited: Does It Answer the Needs?” Wilson Library Bulletin 45 (January 1971): 513-14.

33. Documents Expediting Project, Annual Report 19721973 (Washington, DC: Library of Congress, 1974), 1-2.

34. "Notes from LC," Documents to the People 1, no. 2 (December 1972): 4; George A. Shaw, Jr., "Hard to Locate and Out-of-Print Documents," DttP: Documents to the People 3, no. 4 (March 1975): 38-39.

35. Library of Congress, Annual Report of the Librarian of Congress for the Fiscal Year Ending June 30, 1976 (Washington, DC: Library of Congress, 1977), 6.

36. National Foreign Assessment Center, CIA Publications Released to the Public through Library of Congress DOCEX: Listing for 1972-1978 (McLean, VA: National Foreign Assessment Center, 1979), i; Joseph Mahar, personal communication.

37. Shaw, 38-39.

38. Brewster, 944.

39. LeRoy C. Schwarzkopf, "Doc Ex Expands Offerings," DttP: Documents to the People 8, no. 4 (July 1980): 152, 154.

40. Library of Congress, Annual Report of the Librarian of Congress for the Fiscal Year Ending June 30, 1981 (Washington, DC: Library of Congress, 1982), 58.

41. Library of Congress, Annual Report of the Librarian of Congress for the Fiscal Year Ending 30 September 1998 (Washington, DC: Library of Congress, 1999), 38; Joseph Mahar, personal communication.

42. Documents Expediting Project, "Documents Expediting Project," 1993, quoted in Andrea Sevetson, "Documents Expediting Project (includes CIA Reference Aids)," email to Govdoc-l, January 7, 1994, https://bit.ly/2S0ImjJ; Joseph Mahar, personal communication. 
43. Joseph Mahar, personal communication; House Committee on Appropriations, Subcommittee on Legislative, Legislative Branch Appropriations for 2004: Hearings, 108th Cong., 1st sess., pt. 1, April 9, 2003, 586, http://purl .access.gpo.gov/GPO/LPS40846.

44. Michael W. Albin to members of Documents Expediting Project, April 5, 2004, University of Hawai'i at Mānoa
Library, Government Documents and Maps Department, Honolulu.

45. "Recommendations of the Depository Library Council," Administrative Notes 25, no. 7 (June 15, 2004): 16, https:// bit.ly/2C8E53C.

\section{Appendix: List of DocEx Member Libraries}

Note: This list, which may be incomplete, was compiled from LC annual reports, DocEx bulletins, DocEx annual reports, and other sources. Please contact the author with corrections (gsinclai@hawaii.edu). Corrections received by September 1, 2019 will be published in the Winter 2019 issue of $D t t P$.

Air University
Alfred State College
American Institute for Research
American University
Antioch College
Arizona State University
Arkansas State University
Association of the Bar of the City of New
York
Auburn University
Ball State University
Boston College
Boston Public Library
Bowling Green State University
Brigham Young University
Brookhaven National Laboratory
Brooklyn College
Brooklyn Public Library
Brown University
California State Library
California State University, Chico
California State University, Fresno
California State University, Hayward
California State University, Long Beach
California State University, Los Angeles
California State University, Northridge
California State University, San Diego
California State University, San Francisco
Carnegie Library of Pittsburgh
Central Michigan University
Cincinnati Public Library
Cleveland Public Library
College of William and Mary
Colorado State Library
Colorado State University
A

Air University

Alfred State College

American Institute for Research

American University

Antioch College

Arizona State University

Arkansas State University

York

Auburn University

Ball State University

Boston Public Library

Bowling Green State University

Brigham Young University

Brookhaven National Laboratory

Brooklyn College

Brooklyn Public Library

California State Library

California State University, Chico

California State University, Fresno

California State University, Hayward

California State University, Long Beach

California State University, Los Angeles

California State University, Northridge

California State University, San Diego

California State University, San Francisco

Carnegie Library of Pittsburgh

Cincinnati Public Library

Cleveland Public Library

College of William and Mary

Colorado State University
Columbia University

Community College of Philadelphia

Cornell University

Dallas Public Library

Dartmouth College

Detroit Public Library

Drake University

Duke University

Eastern Michigan University

Eastern Washington State University

Emory University

Enoch Pratt Free Library

Florida International University

Florida State University

Free Library of Philadelphia

George Mason University

Georgetown University

Georgia Institute of Technology

Harvard University

Harvard University Graduate School of Education

Honnold Library (Claremont, CA, Colleges)

Hoover Institution

Hunter College

Idaho State University

Illinois State Library

Illinois State University

Indiana State Library

Indiana State University

Indiana University

Iowa State University of Science and Technology

Johns Hopkins School of Advanced International Studies
Johns Hopkins University

Kansas City Public Library

Kansas State University

Kent State University

Law Library of the University of Texas

Lehigh University

Lesley University

Library of Congress

Linda Hall Library

Los Angeles County Law Library

Los Angeles County Public Schools

Los Angeles Public Library

Louisiana State University

Lyndon State College

Massachusetts Institute of Technology

Miami University

Michigan State University

Midwest Inter-Library Center

Milwaukee Public Library

Minneapolis Public Library

Mississippi State University

Montgomery County (MD) Board of

Education

Mount Holyoke

Nassau Library System

National Indian Law Library

National Library of Medicine

New York Public Library

New York State Library

New York University

New York University Law Library

North Carolina State College

North Texas State University

Northeastern Illinois University

Northern Illinois University 
Northwestern University

Oakland University (MI)

Oberlin College

Occidental College

Ohio State University

Ohio University

Oklahoma State Library

Oklahoma State University

Oregon State Department of Education

Oregon State University

Pennsylvania State Library

Pennsylvania State University

Portland State University

Princeton University

Purdue University

Readex Microprint Corporation

Rutgers University

San Diego State University

San Francisco Public Library

San Francisco State University

University of Illinois at Springfield

Southern Illinois University

Southern Methodist University

Stanford University

State University of New York at

Binghamton

State University of New York at Buffalo

State University of New York at Geneseo

State University of New York at Potsdam

State University of New York at Stony

Brook

State University of New York at Oneonta

Stetson University

Syracuse University

Temple University

Texas Christian University

Texas State Library

U.S. Department of Justice Library

United Nations Library

United States Military Academy

University Microfilms
University of Akron

University of Alabama

University of Alaska

University of Arizona

University of Arkansas

University of Bridgeport

University of California at Los Angeles

University of California at Santa Barbara

University of California at Santa Cruz

University of California, Berkeley

University of California, Davis

University of California, Irvine

University of California, Riverside

University of Central Oklahoma

University of Chicago

University of Cincinnati

University of Colorado, Boulder

University of Delaware

University of Florida

University of Georgia

University of Hawai'i i at Mānoa

University of Idaho

University of Illinois at Chicago

University of Illinois at

Urbana-Champaign

University of Iowa

University of Kansas

University of Kentucky

University of Louisville

University of Maine

University of Maryland

University of Massachusetts

University of Miami

University of Michigan

University of Minnesota

University of Missouri

University of Nebraska

University of Nevada, Reno

University of New Hampshire

University of New Mexico

University of North Carolina
University of Northern Iowa

University of Notre Dame

University of Oregon

University of Pennsylvania

University of Pennsylvania Biddle Law

Library

University of Pittsburgh

University of Rhode Island

University of Rochester

University of South Alabama

University of South Carolina

University of South Florida

University of Southern California

University of Southern Mississippi

University of Tennessee, Knoxville

University of Tennessee, Nashville

University of Texas at Arlington

University of Texas at Austin

University of Utah

University of Vermont

University of Virginia

University of Washington

University of Wisconsin, Madison

University of Wisconsin, Milwaukee

University of Wyoming

University of Oklahoma

Utah State University

Vanderbilt University

Vassar College

Washington State Library

Washington State University

Wayne State University

Wesleyan University

West Virginia University

Western Illinois University

Western Kentucky University

Western Michigan University

Wisconsin Historical Society

Wisconsin State University, Stevens Point

Wittenberg University

Yale University 